\title{
TINJAUAN KELAYAKAN SINTESIS SELULOSA ASETAT DARI PEMANFAATAN SELULOSA LIMBAH ORGANIK
}

\author{
Gema Fitriyano ${ }^{1)}$, Syamsudin Abdullah ${ }^{1)}$ \\ 1) Jurusan Teknik Kimia Fakultas Teknik Universitas Muhammadiyah Jakarta \\ gema_fitriyanost@yahoo.com
}

\begin{abstract}
Cellulose acetate can be applied to various types of products such as films, fibers, membranes, magnetic tape and many other applications. Research on cellulose acetate applications continue to grow in recent years. But this need not be supported by the availability of sources of raw material cellulose. Cellulose from tree trunks wood had to be replaced use by utilizing other sources as raw material. In this study conducted a review of the feasibility of synthesis of cellulose acetate cellulose utilization of organic waste. Several types of organic wastes that are taught in this study is the banana peel waste, sewage treatment and industrial wastewater in order to know. The results of this study show that the use of cellulose from organic waste is still not viable for use in the synthesis of cellulose acetate, this was due to the banana peel waste and wastewater know contains cellulose is low and problems on the storage of waste. While the processing of waste in order to have a problem on accumulation of less waste and use the synthesis method is not optimal. Further research is needed on how the waste storage and selection methods of synthesis.
\end{abstract}

Keywords: organic waste, cellulose acetate, synthesis

ABSTRAK. Selulosa asetat dapat diaplikasikan pada berbagai jenis produk diantaranya sebagai film, serat, membran, pita perekam suara dan banyak aplikasi lainnya. Penelitian tentang aplikasi selulosa asetat terus berkembang belakangan ini. Namun kebutuhan tersebut tidak didukung oleh ketersediaan sumber bahan baku selulosa. Selulosa dari kayu batang pohon sudah harus digantikan penggunaannya dengan memanfaatkan sumber lain sebagai bahan baku. Pada kajian ini dilakukan tinjauan kelayakan sintesis selulosa asetat dari pemanfaatan selulosa limbah organik. Beberapa jenis limbah organik yang dipelajari pada kajian ini adalah limbah kulit pisang, limbah pengolahan agar dan limbah cair industri tahu. Hasil studi ini memperlihatkan bahwa pemanfaatan selulosa dari limbah organik masih belum layak untuk digunakan dalam sintesis selulosa asetat, hal ini disebabkan karena limbah kulit pisang dan limbah cair industri tahu memiliki kandungan selulosa yang rendah dan masalah pada penyimpanan limbahnya. Sedangkan pada limbah pengolahan agar memiliki permasalahan pada akumulasi jumlah limbah yang sedikit dan penggunaan metode sintesis yang belum optimal. Diperlukan penelitian lebih lanjut terkait cara penyimpanan limbah dan pemilihan metode sintesis.

Kata kunci: limbah organik, selulosa asetat, sintesa 


\section{PENDAHULUAN}

Selulosa asetat merupakan bahan yang banyak digunakan dan diteliti pada berbagai jenis aplikasi. Contoh penggunaan produk selulosa asetat diantaranya sebagai film, serat, membran, pita perekam suara dan banyak aplikasi lainnya.

Saat ini sebagai bahan baku utama pada sintesis selulosa asetat hanya mengandalkan selulosa dari serat batang kayu dan serat kapuk sebagai sumber utamanya. Sedangkan batang kayu dan kapuk sudah banyak digunakan untuk membuat produk lain yang lebih komersil.

Karena kayu dan kapuk jumlahnya terbatas dan sudah termanfaatkannya secara komersil, maka dibutuhkan sumber bahan baku selulosa alternatif.

Limbah organik memiliki potensi untuk menjawab tantangan tersebut sebagai sumber bahan baku alternatif, hal ini karena ketersediaannya yang tidak mengenal waktu. Setiap harinya limbah organik dihasilkan dan tidak termanfaatkan.

Limbah digolongkan menjadi dua yaitu limbah organik dan anorganik. Limbah anorganik seperti plastik dan logam tidak dapat diolah dengan cara memanfaatkan aktifitas organisme hidup, sehingga sampah anorganik juga disebut sebagai non-biodegradable waste

Beberapa limbah yang termasuk organik atau biodegradable waste adalah sisa makanan, tumbuhan, hewan, kertas, dan manure. Sekitar 95\% dari limbah pasar tradisional merupakan limbah organik (Sirin, 2011)

Beberapa limbah organik merupakan sumber selulosa yang mungkin dapat dijadikan sebagai alternatif. Limbah organik tersebut diantaranya adalah limbah kulit pisang, limbah pengolahan agar dan limbah cair industri tahu.

Tinjauan kelayakan sintesis selulosa asetat dari limbah organik bertujuan untuk mendapatkan sumber alternatif yang dapat memenuhi kebutuhan dari permasalahan tersebut.

\section{METODE}

Pada kajian ini dilakukan pengumpulan data dari beberapa hasil penelitian terkait sintesis selulosa asetat yang pernah dilakukan sebelumnya dengan sumber selulosa dari bahan baku alternatif yaitu limbah organik.

Analisa dilakukan terhadap ketersediaan bahan baku, ketahanan bahan baku, proses preparasi dan proses sintesis. Hasil dari analisa kelayakan akan diperlihatkan secara menyeluruh agar dapat dianggap mampu untuk diaplikasikan secara komersil.

Hasil penelitian yang disajikan datanya hanya mencakup dari bahan baku limbah kulit pisang, limbah pengolahan agar dan limbah cair industri tahu.

\section{HASIL DAN PEMBAHASAN}

Pada pembahasan ini akan menjelaskan satu per satu berdasarkan jenis bahan baku limbah organik. Dimulai dari limbah kulit pisang, dimana limbah tersebut merupakan limbah domestik yang mudah ditemui.

\section{Limbah Kulit Pisang}

Kulit pisang sebagai sumber selulosa dapat dijadikan bahan baku karena ketersediannya yang tidak mengenal musim, kulit pisang dapat dikumpulkan dari limbah tukang jajanan gorengan di berbagai tempat dan juga dapat dikumpulkan dari industri kecil pengolahan panganan pisang.

Selain nilainya yang kurang ekonomis limbah kulit pisang juga masih belum dimanfaatkan potensinya secara massif. Sehingga terbuka peluang untuk memanfaatkan sebagai bahan baku sintesis selulosa asetat. (Gema, 2016)

Kulit pisang mudah mengalami pembusukan dan degradasi terjadi sangat cepat jika sudah dilakukan pengupasan dari buah. Kulit pisang hanya bertahan 
kurang dari 1 hari, hal ini mengakibatkan rantai proses pengolahan harus dipercepat jika ingin memanfaatkan limbah kulit pisang sebagai bahan baku.

Karena jika tidak segera diolah, kulit pisang yang sudah dikumpulkan akan segera membusuk dan tidak dapat dimanfaatkan lagi selulosanya.

Preparasi limbah kulit pisang untuk mendapatkan selulosa dilakukan dengan mencacah kulit pisang sampai ukuran kecil. Setelah didapatkan kulit pisang dengan ukuran kecil lalu dimasukkan ke dalam larutan $\mathrm{NaOH} 17,5 \%$.
Campuran dibiarkan selama 1 jam, lalu disaring sambil dinetralisasi dengan aquadest pada suhu $40^{\circ} \mathrm{C}$. Dari preparasi bahan baku limbah kulit pisang didapatkan selulosa sebesar 18\%. (Ferdina, 2016)

Selulosa yang didapatkan dari limbah kulit pisang selanjutnya direaksikan dengan asam asetat dan anhidrida asetat untuk sintesis selulosa asetat melalui reaksi asetilasi.

Reaksi asetilasi dilakukan selama 6 jam pada suhu $45{ }^{\circ} \mathrm{C}$ dengan pengadukan perlahan secara konstan sepanjang reaksi. Dari reaksi asetilasi dengan metode ini didapatkan yield selulosa asetat sebesar 50\%. (Gema, 2016)

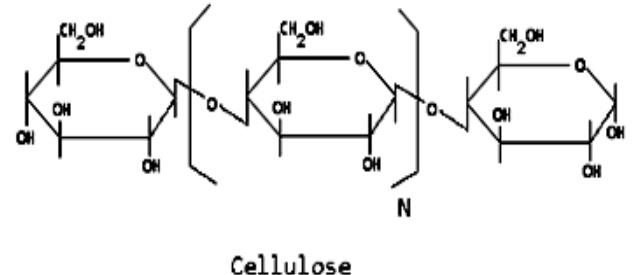

$\mathrm{CH}, \mathrm{COOH}+$ Acetic anhydride/H,SO.

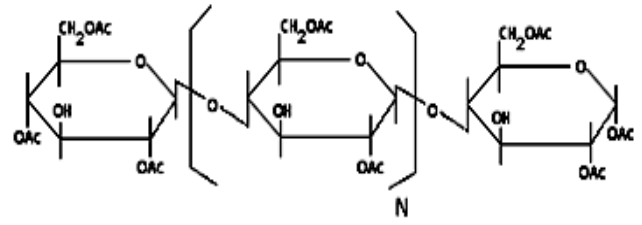

Cellulose acetate

Gambar 1. Reaksi Asetilasi Selulosa

Secara garis besar walaupun limbah kulit pisang hanya mengandung $18 \%$ selulosa, tapi dengan akumulasi yang cukup besar per harinya limbah kulit pisang akan dapat mengimbangi jumlah kebutuhan selulosa yang selama ini bersumber dari kayu maupun kapas.

kelemahan dari pemanfaatan limbah kulit pisang sebagai sumber alternatif pada sintesis selulosa asetat terdapat pada penanganan dan penyimpanan limbah kulit pisang itu sendiri. Hal ini dikarenakan waktu simpan dari kulit pisang yang sangat pendek, sehingga harus segera diproses sebelum kulit pisang mengalami pembusukan.

\section{Limbah Pengolahan Agar}

Berdasarkan data yang terdapat pada situs Kementrian Perindustrian setidaknya terdaftar 13 perusahaan produsen agar yang menghasilkan limbah pengolahan agar. Produsen agar tersebut tersebar di beberapa provinsi di Indonesia, akan tetapi jumlah industri agar terbanyak terdapat di pulau Jawa (Kemenperin, 2016)

Industri pengolahan Agar biasanya menghasilkan produk samping berupa limbah padat. Limbah tersebut terakumulasi setiap hari dan belum ada pemanfaatan yang optimal untuk mengurangi dampak lingkungan dari penumpukan limbah hasil pengolahan agar.

Dibalik itu ternyata limbah pengolahan agar memiliki potensi yang cukup besar untuk digunakan sebagai bahan baku alternatif pada sintesis selulosa asetat. Hal ini dikarenakan limbah pengolahan agar memiliki kadar selulosa yang cukup tinggi, yaitu sebesar 24\% (Nurhayati, 2014).

Preparasi limbah Sebelum digunakan sebagai bahan baku, limbah pengolahan agar di ekstraksi untuk menghilangkan sisa agar dengan cara pemasakan dalam 
air mendidih selama 1 jam, kemudian dicuci dengan air panas hingga air cucian jernih, lalu dijemur dan digiling menjadi tepung limbah pengolahan agar.

Tepung limbah pengolahan agar hasil preparasi digunakan sebagai bahan baku sintesis selulosa asetat, ditambahkan larutan anhidrida asetat dengan perbandingan selulosa sebesar $1: 10$ (selulosa : anhidrida asetat).

Reaksi berlangsung pada suhu $50{ }^{\circ} \mathrm{C}$ dengan pengadukan selama reaksi menggunakan magnetic stirrer. Setelah waktu reaksi selesai, campuran hasil reaksi didiamkan selama 14 jam pada suhu ruang dilanjutkan dengan penyaringan.

$\mathrm{Ke}$ dalam filtrat hasil penyaringan, ditambahkan air setetes demi setetes sampai terbentuk endapan. Endapan yang diperoleh dipisahkan dari larutan, kemudian dicuci hingga netral lalu dikeringkan pada suhu $70{ }^{\circ} \mathrm{C}$ dalam oven inkubator selama 24 jam. Produk yang dihasilkan berupa serbuk putih selulosa asetat.

Dari hasil reaksi asetilasi seluloas didapatkan yield yang cukup kecil yaitu sebesar $26 \%$. Hal ini dikarenakan reaksi berlangsung pada suhu $50{ }^{\circ} \mathrm{C}$, dimana suhu tersebut merupakan suhu maksimum.

Reaksi Asetilasi sebaiknya berjalan pada rentang suhu antara $40{ }^{\circ} \mathrm{C}$ sampai $50^{\circ} \mathrm{C}$. Jika reaksi dijalankan pada suhu $50{ }^{\circ} \mathrm{C}$ atau lebih, maka akan memungkinkan bahan untuk lebih mudah menguap dan sebagian yang tersisa akan rusak karena panas. Sehingga mengurangi jumlah produk selulosa asetat.

Kelemahan dari pemanfaatan limbah pengolahan agar jika dibandingkan dengan limbah kulit pisang adalah pada akumulasinya. Karena pengumpulan limbah pengolahan agar hanya dapat dilakukan dari industri agar saja. jadi dari segi jumlah, limbah agar akan lebih sedikit dibandingkan limbah kulit pisang.
Akan tetapi yang perlu diperhatikan adalah limbah pengolahan agar memiliki fasa padat sehingga pengolahannya cukup mudah dan dapat disimpan dalam waktu yang lama sebelum diproses lebih lanjut.

\section{Limbah Cair Industri Tahu}

Mengacu pada data Kementerian Perindustrian tercatat 147 perusahaan produsen tahu yang terdaftar, dimana jumlah ini belum termasuk produsen tahu skala usaha mikro kecil menengah yang jumlahnya dapat mencapai ratusan.

Hal ini yang memperlihatkan bahwa limbah tahu memiliki potensi yang sangat besar jika akan dimanfaatkan sebagai sumber bahan baku alternatif pada sintesis selulosa asetat (Kemenperin, 2016).

Didasarkan pada banyaknya jumlah limbah cair tahu yang dihasilkan dari proses produksi tahu yaitu sebesar 3000 5000 liter dari satu ton tahu.

Limbah cair dari produksi tahu sangat mudah mengalami degradasi, karena merupakan sumber nutrisi bagi bakteri pembusukan. Jadi jika limbah cair pengolahan tahu ingin dimanfaatkan untuk menghasilkan selulosa, maka proses pengolahan harus dilakukan secara langsung atau penyimpanan agar tidak dalam waktu yang cukup lama.

Proses preparasi Limbah cair industri tahu yang digunakan adalah sisa penggumpalan (whey) yang masih segar sebanyak 1 liter yang diendapkan kemudian disaring dengan kain saring untuk menghilangkan kotoran dari limbah.

Whey tahu dipanaskan pada suhu $100 \pm 2$ ${ }^{\circ} \mathrm{C}$ selama 15 menit sambil diaduk-aduk. Pemanasan ini bertujuan untuk mematikan mikroorganisme.

Selanjutnya preparasi dilakukan dengan cara fermentasi menggunakan kultur Kombucha dengan nutrisi sukrosa \& ammonium sulfat. Fermentasi dilakukan dengan cara aerob dengan udara mengalir bebas di ruang yang sudah disterilisasi. Setelah itu disimpan pada ruang 
fermentasi yang bersih dan gelap. Fermentasi dilakukan selama 14 hari. (Judoamidjojo, 1992)

Hasil dari preparasi limbah cair pengolahan tahu didapatkan jumlah selulosa tertinggi sebesar $6 \%$. preparasi dengan limbah cair industri tahu kurang optimum jika ingin dijadikan sebagai sumber bahan baku sintesa selulosa asetat karena jumlah hasil yang sedikit, terpengaruh banyak faktor dan waktu preparasi yang cukup lama.
Selulosa yang dihasilkan dari preparasi limbah cair pengolahan tahu diasetilasi dengan anhidrida asetat dengan menggunakan katalis asam sulfat pekat, waktu reaksi selama 20 jam pada suhu 40 ${ }^{\circ} \mathrm{C}$. Dari hasil reaksi asetilasi didapatkan yield selulosa asetat sebanyak 39\%. (Irnia, 2007)

Berdasarkan data yang telah dipaparkan sebelumnya, dari ketiga sumber alternatif bahan baku sintesis selulosa asetat. Maka dapat disajikan ringkasannya di dalam tabel berikut :

Tabel 1. Perbandingan kandungan selulosa dan yield selulosa asetat dari beberapa jenis limbah organik

\begin{tabular}{lcc}
\hline Bahan Baku & $\begin{array}{c}\text { Kadar } \\
\text { Selulosa (\%) }\end{array}$ & $\begin{array}{c}\text { Yield Selulosa } \\
\text { Asetat (\%) }\end{array}$ \\
\hline Limbah Kulit Pisang & 18 & 50 \\
Limbah Pengolahan Agar & 24 & 26 \\
Limbah Cair Industri Tahu & 6 & 39 \\
\hline
\end{tabular}

Dari data tersebut dapat dilihat bahwa Limbah pengolahan Agar menghasilkan selulosa yaitu sebesar $24 \%$, dimana jumlah tersebut lebih banyak dibandingkan dengan limbah lainnya.

Sedangkan data dari yield selulosa asetat memperlihatkan limbah pengolahan agar berada di posisi terakhir dengan yield sebesar $26 \%$. Hal ini dikarenakan reaksi berlangsung pada suhu $50{ }^{\circ} \mathrm{C}$, dimana suhu tersebut merupakan suhu maksimum.

Reaksi Asetilasi sebaiknya berjalan pada rentang suhu antara $40{ }^{\circ} \mathrm{C}$ sampai $50{ }^{\circ} \mathrm{C}$, jika suhu lebih rendah akan mengakibatkan reaksi berjalan dengan laju reaksi yang lambat.

Jika reaksi dijalankan pada suhu $50{ }^{\circ} \mathrm{C}$ atau lebih, maka akan memungkinkan bahan untuk lebih mudah menguap dan sebagian lagi terpapar panas. Sehingga mengakibatkan bahan yang tersisa menjadi rusak dan mengurangi jumlah dari hasil reaksi. (Das, 2014)

Dari segi jumlah limbah, limbah cair industri tahu merupakan sumber tertinggi yang dapat dijadikan sumber bahan baku alternatif sintesis selulosa asetat.

Sedangkan limbah agar berada di urutan terakhir karena dari sisi volume limbah yang dihasilkan jumlahnya sangat kecil, hal ini dibuktikan oleh data kemenperin dimana hanya terdapat 13 perusahan produsen agar yang terdaftar.

Berdasarkan ketahanan penyimpanan dari bahan baku, limbah pengolahan agar merupakan bahan baku yang dapat disimpan dalam waktu yang cukup lama dibandingkan dengan limbah kulit pisang dan limbah cair industri tahu.

Ketahanan dari limbah selama penyimpanan berpengaruh terhadap lama waktu pengumpulan, pendistribusian dan proses pengolahan. Limbah kulit pisang dan limbah cair industri tahu sangat cepat mengalami pembusuka sehingga akan sulit dalam pemanfaatannya karena diharuskan untuk diproses segera agar tidak busuk.

Pemanfaatan masing-masing limbah organik memilki kekurangan dan kelebihan masing-masing. Dari segi kelayakan sumber, limbah cair industri tahu dianggap 
layak untuk menjadi sumber alternatif bahan baku sintesis selulosa asetat.

Akan tetapi volume saja tidak cukup dijadikan patokan karena limbah agar memiliki kandungan selulosa lebih tinggi dibandingkan limbah lainnya.

Untuk proses sintesis sebaiknya dipilih cara terbaik agar didapatkan yield yang tinggi. Kelemahan pada penelitian sintesis selulosa asetat dari selulosa limbah cair industri tahu adalah pemilihan fermentasi yang menyebabkan waktu sintesis menjadi lama dengan hasil yang kurang optimum.

\section{KESIMPULAN DAN SARAN}

Dari ketiga sumber limbah organik yang telah dikaji, seluruhnya dianggap belum layak untuk dimanfaatkan sebagai bahan baku alternatif pada sintesis selulosa asetat.

Hal ini karena limbah kulit pisang dan limbah cair industri tahu memiliki kandungan selulosa yang rendah dan masalah pada penyimpanan limbahnya. Sedangkan pada limbah pengolahan agar memiliki permasalahan pada akumulasi jumlah limbah yang sedikit dan penggunaan metode sintesis yang belum optimal.

Dari segi ketersediaan limbah, aspek ini bertolak belakang dengan proses preparasinya. Pada kondisi aktual limbah yang jumlah akumulasinya sedikit lebih mudah disimpan dan dipreparasi, tapi kondisi sebaliknya terjadi pada limbah yang jumlahnya banyak memiliki masalah pada waktu penyimpanannya.

Dibutuhkan kajian lebih lanjut untuk melakukan kombinasi antara pemilihan bahan baku limbah organik yang mengandung kadar selulosa tinggi dengan optimasi proses sintesis selulosa asetat sehingga didapatkan hasil yang optimum.

\section{DAFTAR PUSTAKA}

Arniz, H. 1992. Sintesis dan Karakterisasi Membran Selulosa Asetat Dari Limbah Cair Tahu Untuk Aplikasi Baterai Ion Lithium. Laporan Penelitian UNY. Yogyakarta.

Das, A.M. 2014. Synthesis and characterization of cellulose acetate from rice husk: Eco-friendly condition. Elsevier : Carbohydrate Polymers, 2014. 112: p. 342 - 349.

Ferdina O. F., Widya F., dan Gema F., 2016 Pengaruh Rasio Berat Antara Serat Kulit Pisang Dengan Serat Kertas Koran Bekas dan Serat Batang Jagung dengan Serat Kertas Koran Bekas terhadap Indeks Tarik dan Indeks Sobek Kertas Recycle. Semnastek UMJ. Jakarta.

Gema, F. dan Syamsudin, AB. 2016. Pemanfaatan Kulit Pisang Untuk Pembuatan Filter Selulosa Asetat Diaplikasikan Sebagai Masker Asap Rokok. Semnastek UMJ. Jakarta.

Irnia, N. \& Nur, H., \& Yaumadina, A., 2007 Produksi Selulosa Menggunakan Kultur Kombucha dari Limbah Cair Industri Tahu. Jurnal Teknologi Pertanian, Vol, 8 No.2 95-102. Malang.

Judoamidjojo, M, A. A. Darwis, dan E. G. Sa'id. 1992. Teknologi Fermentasi. Rajawali Press. Jakarta.

Kemenperin. 2016. Direktori Perusahaan Industri. http: // www.kemenperin.go.id / direktori perusahaan ? What = agar -agar \& prov $=0$.

Kemenperin. 2016. Direktori Perusahaan Industri. http : // www. Kemenperin .go id / direktori -perusahaan ? what $=$ tahu \& prov $=0 \&$ ha $=3$ Nurhayati \& Rinta, K., 2014 Sintesis
Selulosa Asetat dari Limbah
Pengolahan Agar. Balai Besar
Penelitian dan Pengembangan 


$\begin{array}{lll}\text { Pengolahan } & \text { Produk dan } \\ \text { Bioteknologi } & \text { Kelautan } & \text { dan }\end{array}$

Perikanan. Jakarta.

Sirin, F., Salafudin, Lathifa R. \& Emma A, 2011 Pemanfaatan Sampah Organik

Secara Padu Menjadi Alternatif Energi : Biogas dan Precursor

Briket. Prosiding Seminar Nasional Teknik Kimia "Kejuangan".

Yogyakarta. 
